IIIIIIIIIIIIIIIIIIIIIIIIIIIIIIIIIIII

Original Article

IIIIIIIIIIIIIIIIIIIIIIIIIIIIIIIIIII

\title{
Species differences in the developmental toxicity of procymidone -Remarkable variation in pharmacokinetics, metabolism, and excretion-
}

\author{
Yoshitaka Tomigahara, ${ }^{1, *}$ Hirokazu Tarui, ${ }^{1}$ Hirohisa Nagahori, ${ }^{1}$ Kenji Sugimoto, ${ }^{2}$ \\ Masayuki Mogi, ${ }^{3}$ Kazuhiko Nishioka, ${ }^{1}$ Satoshi Kawamura, ${ }^{1}$ Naohiko Isobe, ${ }^{1}$ \\ Yasuyoshi OKuno ${ }^{1}$ and Hideo KaneKo ${ }^{1}$ \\ ${ }^{1}$ Environmental Health Science Laboratory, Sumitomo Chemical Co., Ltd., \\ 3-1-98, Kasugadenaka, Konohana-ku, Osaka 554-8558, Japan \\ ${ }^{2}$ Mitsubishi Chemical Medience Corporation, 1285 Kurisaki-machi, Uto, Kumamoto 869-0425, Japan \\ ${ }^{3}$ Shin Nippon Biomedical Laboratories, Ltd., 16-1 Minami-akasaka, Kainan, Wakayama 642-0017, Japan
}

(Received February 3, 2015; Accepted May 25, 2015)

\begin{abstract}
There are species differences regarding the developmental toxicity of procymidone (Sumilex ${ }^{\circledR}$ ), a fungicide with a weak antiandrogenic activity. To clarify key factors of these species differences, pharmacokinetic and excretion studies in rats, rabbits, and monkeys were conducted using ${ }^{14} \mathrm{C}$-labeled procymidone. One hydroxylated metabolite of procymidone (Hydroxylated-PCM: very weak anti-androgen) was found to exist longer and at a much higher concentration in rat plasma than in rabbit and monkey plasma. In rabbits and monkeys, Hydroxylated-PCM was transformed into a glucuronic acid conjugate (Hydroxylated-PCMglucuronide: non-anti-androgen) and rapidly excreted into urine as a major metabolite. On the other hand, it was a minor metabolite in rat urine. The results of biliary excretion studies indicated that these species differences were caused by the species differences in the biliary excretion of Hydroxylated-PCM-glucuronide; this variation in biliary excretion rate was concluded to be related to species differences in developmental toxicity. () Pesticide Science Society of Japan

Keywords: species differences, developmental toxicity, pharmacokinetics, metabolism, biliary excretion, enterohepatic circulation.

Electronic supplementary materials: The online version of this article contains supplementary materials (Supplemental Tables S1-S10), which are available at http://www.jstage.jst.go.jp/browse/jpestics/.
\end{abstract}

\section{Introduction}

Procymidone (Sumilex ${ }^{\circledR}$ ) is a fungicide with both protective and curative activities used to control plant diseases, such as fruit rot; gray mold on fruits, vines, and vegetables; and Sclerotinia rot of kidney beans and vegetable crops. ${ }^{1-3)}$ The metabolic pathways of procymidone in mammals are shown in Fig. 1. ${ }^{4-6)}$ Because the imide (cyclic) compounds (procymidone, PCM$\mathrm{CH}_{2} \mathrm{OH}$, and $\mathrm{PCM}-\mathrm{COOH}$ ) and the corresponding imide linkage-cleaved metabolites ( $\mathrm{PCM}-\mathrm{NH}-\mathrm{COOH}, \mathrm{PA}-\mathrm{CH}_{2} \mathrm{OH}$, and $\mathrm{PA}-\mathrm{COOH}$, respectively) are in equilibrium, also shown in Fig. $1{ }^{7)}$ the sum of both components is considered to be an appropriate index for comparing the amounts (concentrations) of metabolites. Therefore, in this report, the following abbreviations are used for procymidone metabolites: PCM (sum of

\footnotetext{
* To whom correspondence should be addressed.

E-mail: tomigahara@sc.sumitomo-chem.co.jp

Published online July 23, 2015

(C) Pesticide Science Society of Japan
}

procymidone and PCM-NH-COOH), Hydroxylated-PCM (sum of PCM- $\mathrm{CH}_{2} \mathrm{OH}$ and PA- $\mathrm{CH}_{2} \mathrm{OH}$ ), Carboxylated-PCM (sum of $\mathrm{PCM}-\mathrm{COOH}$ and PA-COOH), and Hydroxylated-PCM-glucuronide (sum of $\mathrm{PCM}-\mathrm{CH}_{2} \mathrm{OH}$-glucuronide and $\mathrm{PA}-\mathrm{CH}_{2} \mathrm{OH}$ glucuronide). Procymidone is hydroxylated at the methyl group of the imide ring. Hydroxylated-PCM is then metabolized in one of two ways: it is either oxidized at the hydroxyl group to form Carboxylated-PCM or transformed into the glucuronic acid conjugate, Hydroxylated-PCM-glucuronide. CarboxylatedPCM and Hydroxylated-PCM-glucuronide are more hydrophilic and thus more readily excreted than Hydroxylated-PCM. ${ }^{4,5)}$

Many toxicity studies have been conducted to evaluate the safety of procymidone. Procymidone is anti-androgenic in vitro, although its activity is much lower (20-70 times lower) than that of hydroxyflutamide, which is a representative anti-androgenic agent. ${ }^{8,9)}$ When rats were dosed with procymidone at $125 \mathrm{mg} /$ $\mathrm{kg} /$ day in teratogenicity studies (repeated oral administration for 14 days), hypospadias was observed in the vast majority of male pups in all litters. The lowest teratogenic dose level was $37.5 \mathrm{mg} / \mathrm{kg} /$ day in rats. In contrast, no offspring with hypospa- 


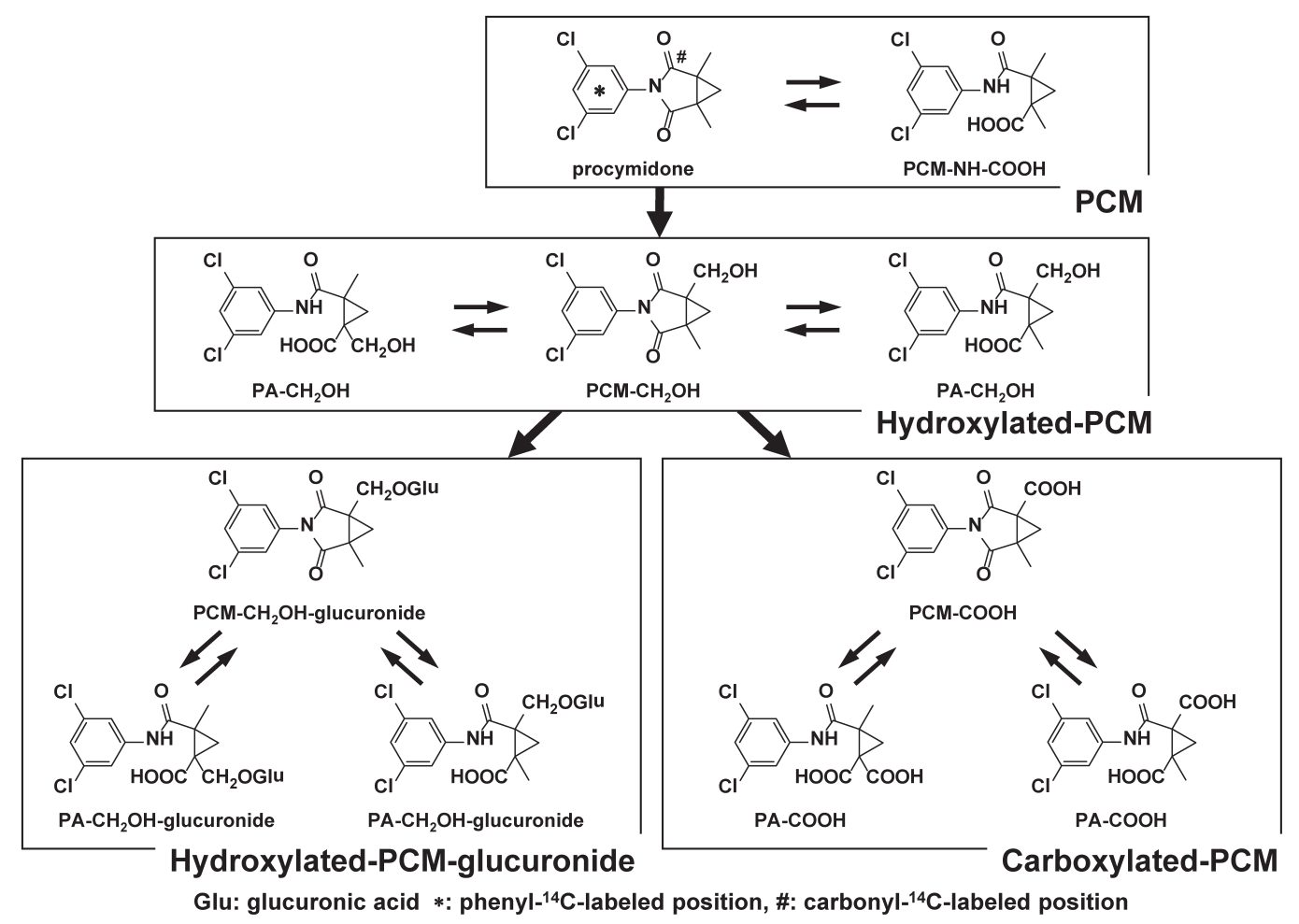

Fig. 1. Proposed main metabolic pathways of procymidone in mammals.

Table 1. Summary of the results for teratogenicity in rats, rabbits and monkeys

\begin{tabular}{lccc}
\hline \multirow{2}{*}{ Species } & \multirow{2}{*}{ Dose $(\mathrm{mg} / \mathrm{kg} /$ day) } & \multicolumn{2}{c}{ Effects on external genitalia (e.g. hypospadias) } \\
\cline { 3 - 4 } & & LOAELs $(\mathrm{mg} / \mathrm{kg} / \mathrm{day})$ & NOAELs $(\mathrm{mg} / \mathrm{kg} / \mathrm{day})$ \\
\hline Rats & $3.5-500$ & 37.5 & 12.5 \\
Rabbits & 125 & Negative & 125 \\
Monkeys & $62.5,125$ & Negative & 125 \\
\hline
\end{tabular}

dias were noted in rabbits or monkeys, even when treated at $125 \mathrm{mg} / \mathrm{kg} /$ day, the highest dose tested (Table 1 ). These results suggest that rats are more sensitive to procymidone exposure than rabbits and monkeys. Thus, a series of mechanistic studies was conducted to determine whether there are species differences related to developmental toxicity in metabolism, excretion, placental transfer, or protein binding among rats, rabbits, monkeys, and humans. The present report pertains to species differences in metabolism and excretion. To clarify key factors of these species differences, pharmacokinetic and excretion studies in rats, rabbits, and monkeys were conducted using ${ }^{14} \mathrm{C}$-labeled procymidone. The results of other studies, including those with human relevance, will be described elsewhere.

\section{Materials and Methods}

\section{Compounds}

Procymidone labeled uniformly in the phenyl group, [phenyl${ }^{14} \mathrm{C}$ ]procymidone (specific radioactivity: $4.48 \mathrm{GBq} / \mathrm{mmol}$, radiochemical purity: $>99 \%$, chemical purity: $>99 \%$, Fig. 1 ), and in the carbonyl group, [carbonyl $-{ }^{14} \mathrm{C}$ ] procymidone, (specific radio- activity: $2.28 \mathrm{GBq} / \mathrm{mmol}$, radiochemical purity: $>99 \%$, chemical purity: $>99 \%$, Fig. 1), was synthesized by Sumitomo Chemical Co., Ltd., Japan. Unlabeled procymidone (chemical purity: 99.2\%) was synthesized by Sumitomo Chemical Co., Ltd. Unlabeled authentic standards, PCM-NH-COOH (chemical purity: 98.6\%), PCM- $\mathrm{CH}_{2} \mathrm{OH}$ (chemical purity: 99.9\%), PCM-COOH (chemical purity: 94.7\%), $\mathrm{PA}-\mathrm{CH}_{2} \mathrm{OH}$ (chemical purity: $98.8 \%$ ), and PA-COOH (chemical purity: 96.9\%), were also synthesized by Sumitomo Chemical Co., Ltd. and were used for the identification of the metabolites. The ${ }^{14} \mathrm{C}$-labeled procymidone was diluted with unlabeled procymidone to achieve the appropriate specific radioactivity. The labeled and unlabeled test substances were dissolved in corn oil (rats) or suspended in a $0.5 \%$ methylcellulose solution (rabbits and monkeys) ( $5 \mathrm{~mL} / \mathrm{kg}$ body weight). In an earlier study, it was demonstrated that these different vehicles caused no effects on pharmacokinetics or excretion.

\section{Animal husbandry}

Crj: CD (SD strain) IGS female rats aged 6 weeks were purchased from Charles River Japan Inc.; Kbs: NZW female rab- 
bits aged 12 weeks from Kitayama Labes Co., Ltd., Japan; and female cynomolgus monkeys aged 4-6 years from the Guangxi Research Center of Primate Laboratory Animals, China. The animals were maintained in an air-conditioned room at $22-26^{\circ} \mathrm{C}$ (rats), $22-25^{\circ} \mathrm{C}$ (rabbits), and $22-28^{\circ} \mathrm{C}$ (monkeys) with an alternating 12-hr light and 12-hr dark cycle. For rats and rabbits, water and pelleted diet (CRF-1 (rats), RC4 (rabbits), Oriental Yeast Co., Ltd., Japan) were provided ad libitum. For monkeys, water was provided ad libitum and approximately $108 \mathrm{~g}$ of solid food (Teklad Global Certified 25\% Protein Primate Diet, Harlan Sprague Dawley Inc., USA) was provided to the animals once a day. All studies were approved by the committee concerning animal protection at each laboratory and were performed in accordance with their established ethical standards.

\section{Animal treatment}

Because all metabolites could be detected and quantitated with either of the labeled preparations ([phenyl- $\left.{ }^{14} \mathrm{C}\right]$ procymidone or [carbonyl- ${ }^{14} \mathrm{C}$ ] procymidone), [phenyl- ${ }^{14} \mathrm{C}$ ] procymidone was used in the pharmacokinetic and excretion studies (single dose and repeated dose), and [carbonyl- ${ }^{14} \mathrm{C}$ ] procymidone was employed for the biliary excretion studies. Hereafter, [phenyl- ${ }^{14} \mathrm{C}$ ]procymidone and [carbonyl- ${ }^{14} \mathrm{C}$ ]procymidone are both designated as ${ }^{14} \mathrm{C}$-procymidone.

3.1. Single-administration pharmacokinetic and excretion studies

After quarantine (at least 1 week), ${ }^{14} \mathrm{C}$-procymidone was administered orally at dosages of 37.5 (rats only), 62.5, 125, 250, and $500 \mathrm{mg} / \mathrm{kg}$ to animals in two groups (one group for the pharmacokinetic study and the other for the excretion study: rats, 4 animals/group; rabbits and monkeys, 3 animals/group). The radiation dose was set at about $3.70 \mathrm{MBq} / \mathrm{kg}$. For the pharmacokinetic studies, blood was collected from the caudal vein (rats), an auricular vein (rabbits), a femoral vein (monkeys), or the abdominal aorta (at $120 \mathrm{hr}$ only for rats and rabbits) 1, 2, 4, 6 (rats only), $8,10,12,24,48,72$, and $120 \mathrm{hr}$ after administration. For the excretion studies, after administration, animals were housed individually in metabolic cages to allow separate collection of urine and feces. Urine and feces from each animal were collected 6 (urine only), 24, 48, 72, and $120 \mathrm{hr}$ after administration. After the final samples had been taken, the rats were sacrificed by exsanguination via the abdominal aorta, and the carcasses were obtained.

\subsection{Repeated-administration pharmacokinetic and excretion} studies

After quarantine (at least 1 week), ${ }^{14} \mathrm{C}$-procymidone was administered orally once a day at doses of 37.5 (rats only), 62.5, 125,250 , and 500 (monkeys only) $\mathrm{mg} / \mathrm{kg}$ for 14 days to rats and monkeys in each group (rats, 4 animals/group; monkeys, 3 animals/group). The dose of radiation was set at about $1.2 \mathrm{MBq} / \mathrm{kg}$. After the first administration, animals were housed individually in metabolic cages to allow the separate collection of urine and feces. Blood was collected from the caudal vein (rats), a femoral vein (monkeys), or the abdominal aorta (rats only, $120 \mathrm{hr}$ after the 14th dosing) 2, 4, 8, and $24 \mathrm{hr}$ after the $1 \mathrm{st}, 3 \mathrm{rd}, 7 \mathrm{th}, 10 \mathrm{th}$, and 14 th oral dosing, and 48,72 , and $120 \mathrm{hr}$ after the 14 th dosing. Urine and feces from each animal were collected 1, 2 (monkeys only), 3, 4, 5, 7, 9, 11, 13, 14, 16, and 19 days after the first administration. After the final samples had been taken, the rats were sacrificed by exsanguination via the abdominal aorta, and the carcasses were obtained.

\subsection{Biliary excretion studies}

After quarantine (at least 1 week), animals were anesthetized and laparotomized for the insertion of a cannula into the common bile duct. After the animals had awoken from the anesthesia, ${ }^{14} \mathrm{C}$-procymidone was administered orally at 3.5 (rats) and 62.5 (rats) and 125 (rabbits and monkeys) mg/kg (rats, 4 animals/group; rabbits and monkeys, 1 animal each). The dose level for rabbits and monkeys was different from that for rats, since the latter showed some toxicological effects, such as decreased spontaneous activity, ataxic gait, and/or a prone position at lower dose levels. The dose of radiation set at about $3.70 \mathrm{MBq} /$ $\mathrm{kg}$. After administration, the animals were housed individually in cages to allow for the separate collection of bile, urine, and feces at 6 (bile only), 24, and $48 \mathrm{hr}$ after administration. After the final samples had been taken, animals were sacrificed by exsanguination, and the intestinal tract contents and the carcasses (rats only) were obtained.

\section{Sample processing and radioanalysis}

Blood of each animal was centrifuged $\left(3000 \mathrm{rpm}, 10 \mathrm{~min}, 4^{\circ} \mathrm{C}\right.$, CR5B2, Hitachi Koki Co., Ltd., Japan) to separate the plasma. The radioactivity in the urine, bile, and plasma of each animal was measured by conventional liquid scintillation counting (LSC). To analyze the metabolites, equal amounts of plasma (rats, $50-100 \mu \mathrm{L}$; rabbits, $0.8-1.2-\mathrm{mL}$; monkeys, $0.3-0.8-\mathrm{mL}$ ) at each time point were combined (pooled plasma). The pooled plasma samples were extracted 3 times with 4 times the volume of acetonitrile to obtain extracts and residues. Feces and intestinal contents were extracted several times with 3-5 times the volume of acetonitrile and/or water. Carcasses (rats only) were dissolved in $2 \mathrm{~mol} / \mathrm{L}$ potassium hydroxide. The radioactivity in pooled plasma extracts, fecal extracts, intestinal content extracts, and carcass solutions (rats only) was measured by LSC. The radioactivity in pooled plasma residue, fecal residue, and intestinal content residue was measured by LSC after treatment with tissue solubilizer (Soluene-350, PerkinElmer, Inc., USA) or after combustion with a sample oxidizer (System 307, PerkinElmer, Inc.).

\section{Analysis of metabolites}

In a manner described previously, ${ }^{4-7)}$ qualitative and quantitative analysis of metabolites was conducted by TLC analysis. Silica-gel $60 \mathrm{~F}_{254}$ (thickness: $0.25 \mathrm{~mm}$, E. Merck, Germany) plates were used as TLC plates, and an imaging analyzer (BAS-1800 II, Fuji Photo Film Co., Ltd., Japan) was used as a radio-detector. The solvent systems were as follows: (1) toluene/ethyl formate/formic acid (5:7:1, by vol.) and (2) butanol/acetic acid/ water (6:1:1, by vol.). Qualitative and quantitative analyses of 
metabolites were conducted with an imaging analyzer using the TLC developed by the solvent system (1). For qualitative analysis, TLC co-chromatography with procymidone and authentic standards was conducted to identify metabolites.

Qualitative analysis of rat bile, urine, and fecal extracts, and rabbit urine and fecal extracts in the pharmacokinetic and excretion studies $(20-50 \mu \mathrm{L})$ was conducted to verify individual differences in the metabolic profile of each animal. As a result, it was confirmed that the profiles of metabolites in these samples were not different individually. Accordingly, for quantitative analysis, equal proportions of urine (rats, 1/20; rabbits, 1/100), equal proportions of bile (rats only, 1/50), and equal proportions of fecal extracts (rats, 1/20; rabbits, 1/100) at each time point were mixed (pooled urine, pooled bile and pooled fecal extracts, respectively), and pooled plasma extracts, pooled urine, pooled bile, and pooled fecal extracts $(20-50 \mu \mathrm{L})$ were subjected to TLC analysis. Individual samples of bile, urine, fecal extracts, and intestinal content extracts of monkeys and bile, urine, fecal extracts, and intestinal content extracts of rabbit in the biliary excretion study $(20-50 \mu \mathrm{L})$ were used for both qualitative and quantitative analysis.

For the Hydroxylated-PCM-glucuronide, enzymatic hydrolysis was carried out with a representative urine sample. Urine samples were added to $0.5 \mathrm{~mL}$ of $0.2 \mathrm{~mol} / \mathrm{L}$ acetate buffer $(\mathrm{pH}$ 5.0) and incubated with $\beta$-glucuronidase (containing sulfatase, Type H-1, Sigma-Aldrich Corporation, USA) at $37^{\circ} \mathrm{C}$ for approximately $16 \mathrm{hr}$ for hydrolysis. Following incubation, the mixture was applied to TLC co-chromatography (solvent systems (1) and (2)) to identify aglycones.

\section{Calculations}

\subsection{Calculation of pharmacokinetic parameters}

The maximum plasma concentration $\left(C_{\max }\right)$ and time to reach $C_{\max }\left(T_{\max }\right)$ were determined from the values obtained. The elimination half-life $\left(t_{1 / 2}\right)$ was calculated by linear regression analysis. Areas under the plasma concentration time curves until $120 \mathrm{hr}\left(A U C_{0-120}\right)$ for the single-dose studies and until $24 \mathrm{hr}$ $\left(A U C_{2-24}\right)$ for the repeated-dose studies were calculated using the trapezoidal approximation method. For the single-dose studies, AUC from time 0 to infinity $\left(A U C_{0-\infty}\right)$ after administration was the sum of $A U C_{0-t}$ and $A U C_{t-\infty}$.

6.2. Calculation of the amounts absorbed from the gastrointestinal tract

The oral absorption rate was estimated based on the cumulative urinary excretion rate only. The amounts absorbed from the gastrointestinal tract were calculated as follows: amount absorbed $(\mathrm{mg} / \mathrm{kg})=$ dose level $(\mathrm{mg} / \mathrm{kg}) \times$ oral absorption rate $(\%) / 100=$ dose level $(\mathrm{mg} / \mathrm{kg}) \times$ urinary excretion rate $(\%) / 100$.

\section{Results}

1. Single-administration pharmacokinetic and excretion studies The $C_{\max }$ values for ${ }^{14} \mathrm{C}$ in rabbits administered with ${ }^{14} \mathrm{C}$-procymidone at each dose were similar to those in rats, while those in monkeys were much lower (Table 2). PCM concentrations in rats were higher than those in rabbits and monkeys following a single oral administration. The $C_{\max }$ of PCM in monkeys at a non-teratogenic dose level of $125 \mathrm{mg} / \mathrm{kg} /$ day was lower than that in rats at a teratogenic dose level. However, the $A U C_{0-72}$ and $A U C_{0-\infty}$ of PCM in monkey plasma at $125 \mathrm{mg} / \mathrm{kg}$ were similar to those in rats at $62.5 \mathrm{mg} / \mathrm{kg}$ (Table 3 ). Therefore, it was demon-

Table 2. Pharmacokinetics parameters of ${ }^{14} \mathrm{C}$ in plasma after single oral administration of ${ }^{14} \mathrm{C}$-procymidone to female rats, rabbits and monkeys

\begin{tabular}{|c|c|c|c|c|c|}
\hline \multirow{2}{*}{ Rats } & \multicolumn{5}{|c|}{ Dose $(\mathrm{mg} / \mathrm{kg})$} \\
\hline & 37.5 & 62.5 & 125 & 250 & 500 \\
\hline$C_{\max }(\mu \mathrm{g} / \mathrm{mL})$ & 11.5 & 16.4 & 30.1 & 35.7 & 50.3 \\
\hline$T_{\max }(\mathrm{hr})$ & 8 & 12 & 24 & 24 & 24 \\
\hline$A U C_{0-120}(\mu \mathrm{g} \cdot \mathrm{hr} / \mathrm{mL})$ & 450 & 574 & 1108 & 1389 & 2317 \\
\hline$A U C_{0-\infty}(\mu \mathrm{g} \cdot \mathrm{hr} / \mathrm{mL})$ & 454 & 578 & 1117 & 1401 & 2331 \\
\hline \multirow{2}{*}{ Rabbits } & & \multicolumn{4}{|c|}{ Dose $(\mathrm{mg} / \mathrm{kg})$} \\
\hline & & 62.5 & 125 & 250 & 500 \\
\hline$C_{\max }(\mu \mathrm{g} / \mathrm{mL})$ & & 19.4 & 30.0 & 37.2 & 50.4 \\
\hline$T_{\max }(\mathrm{hr})$ & & 1 & 1 & 1 & 4 \\
\hline$A U C_{0-120}(\mu \mathrm{g} \cdot \mathrm{hr} / \mathrm{mL})$ & & 180 & 251 & 457 & 1244 \\
\hline$A U C_{0-\infty}(\mu \mathrm{g} \cdot \mathrm{hr} / \mathrm{mL})$ & & 189 & 258 & 474 & 1260 \\
\hline \multirow{2}{*}{ Monkeys } & & \multicolumn{4}{|c|}{ Dose $(\mathrm{mg} / \mathrm{kg})$} \\
\hline & & 62.5 & 125 & 250 & 500 \\
\hline$C_{\max }(\mu \mathrm{g} / \mathrm{mL})$ & & 5.9 & 4.4 & 8.8 & 8.7 \\
\hline$T_{\max }(\mathrm{hr})$ & & 10 & 6 & 10 & 4 \\
\hline$A U C_{0-120}(\mu \mathrm{g} \cdot \mathrm{hr} / \mathrm{mL})$ & & 295 & 378 & 563 & 522 \\
\hline$A U C_{0-\infty}(\mu \mathrm{g} \cdot \mathrm{hr} / \mathrm{mL})$ & & 427 & 600 & 754 & 836 \\
\hline
\end{tabular}

Data were calculated from mean value at each time point. 
Table 3. Pharmacokinetics parameters of PCM in plasma after single oral administration of ${ }^{14} \mathrm{C}$-procymidone to female rats, rabbits and monkeys

\begin{tabular}{|c|c|c|c|c|c|}
\hline \multirow{2}{*}{ Rats } & \multicolumn{5}{|c|}{ Dose $(\mathrm{mg} / \mathrm{kg})$} \\
\hline & 37.5 & 62.5 & 125 & 250 & 500 \\
\hline$C_{\max }(\mu \mathrm{g} / \mathrm{mL})$ & 3.72 & 6.80 & 12.84 & 12.01 & 20.27 \\
\hline$T_{\max }(\mathrm{hr})$ & 6 & 4 & 8 & 10 & 6 \\
\hline$A U C_{0-72}(\mu \mathrm{g} \cdot \mathrm{hr} / \mathrm{mL})$ & 40.9 & 89.9 & 227.4 & 236.5 & 575.1 \\
\hline$A U C_{0-\infty}(\mu \mathrm{g} \cdot \mathrm{hr} / \mathrm{mL})$ & 40.9 & 89.9 & 227.4 & 236.5 & 575.1 \\
\hline \multirow{2}{*}{ Rabbits } & & \multicolumn{4}{|c|}{ Dose $(\mathrm{mg} / \mathrm{kg})$} \\
\hline & & 62.5 & 125 & 250 & 500 \\
\hline$C_{\max }(\mu \mathrm{g} / \mathrm{mL})$ & & 0.00 & 0.17 & 0.70 & 1.01 \\
\hline$T_{\max }(\mathrm{hr})$ & & - & 10 & 6 & 1 \\
\hline$A U C_{0-72}(\mu \mathrm{g} \cdot \mathrm{hr} / \mathrm{mL})$ & & 0.0 & 1.8 & 3.5 & 5.0 \\
\hline$A U C_{0-\infty}(\mu \mathrm{g} \cdot \mathrm{hr} / \mathrm{mL})$ & & 0.0 & 1.8 & 3.5 & 5.0 \\
\hline \multirow{2}{*}{ Monkeys } & & \multicolumn{4}{|c|}{ Dose (mg/kg) } \\
\hline & & 62.5 & 125 & 250 & 500 \\
\hline$C_{\max }(\mu \mathrm{g} / \mathrm{mL})$ & & 2.90 & 2.47 & 3.71 & 3.73 \\
\hline$T_{\max }(\mathrm{hr})$ & & 10 & 1 & 10 & 4 \\
\hline$A U C_{0-72}(\mu \mathrm{g} \cdot \mathrm{hr} / \mathrm{mL})$ & & 73.8 & 76.9 & 123.8 & 85.1 \\
\hline$A U C_{0-\infty}(\mu \mathrm{g} \cdot \mathrm{hr} / \mathrm{mL})$ & & 73.8 & 76.9 & 123.8 & 85.1 \\
\hline
\end{tabular}

Data were calculated from mean value at each time point.

-: Not determined.

Table 4. Cumulative ${ }^{14} \mathrm{C}$-recoveries in urine and feces within $120 \mathrm{hr}$ after single oral administration of ${ }^{14} \mathrm{C}$-procymidone to female rats, rabbits and monkeys, and the amounts absorbed from the gastrointestinal tract

\begin{tabular}{|c|c|c|c|c|c|}
\hline \multirow{2}{*}{ Rats } & \multicolumn{5}{|c|}{ Dose (mg/kg) } \\
\hline & 37.5 & 62.5 & 125 & 250 & 500 \\
\hline Urine (\% of dose) & $83.4 \pm 1.1$ & $83.6 \pm 1.6$ & $81.2 \pm 1.7$ & $66.7 \pm 1.8$ & $46.5 \pm 4.1$ \\
\hline Feces (\% of dose) & $11.5 \pm 1.1$ & $11.6 \pm 1.8$ & $14.7 \pm 1.2$ & $28.6 \pm 2.2$ & $48.7 \pm 4.9$ \\
\hline Carcass ( $\%$ of dose) & $0.3 \pm 0.0$ & $0.5 \pm 0.1$ & $0.5 \pm 0.2$ & $0.5 \pm 0.1$ & $0.3 \pm 0.1$ \\
\hline Total & $95.2 \pm 0.5$ & $95.4 \pm 0.1$ & $96.4 \pm 0.7$ & $95.7 \pm 0.8$ & $95.4 \pm 1.1$ \\
\hline Amounts absorbed $(\mathrm{mg} / \mathrm{kg})$ & 31.3 & 52.3 & 101.5 & 166.8 & 232.5 \\
\hline \multirow{2}{*}{ Rabbits } & & \multicolumn{4}{|c|}{ Dose (mg/kg) } \\
\hline & & 62.5 & 125 & 250 & 500 \\
\hline Urine (\% of dose) & & $92.8 \pm 2.0$ & $81.2 \pm 3.1$ & $75.0 \pm 7.1$ & $64.1 \pm 2.8$ \\
\hline Feces (\% of dose) & & $3.7 \pm 3.7$ & $15.8 \pm 2.1$ & $22.1 \pm 7.1$ & $34.8 \pm 4.0$ \\
\hline Total & & $96.6 \pm 1.8$ & $97.0 \pm 1.9$ & $97.1 \pm 2.4$ & $98.9 \pm 1.3$ \\
\hline Amounts absorbed $(\mathrm{mg} / \mathrm{kg})$ & & 58.0 & 101.5 & 187.5 & 320.5 \\
\hline \multirow{2}{*}{ Monkeys } & & \multicolumn{4}{|c|}{ Dose (mg/kg) } \\
\hline & & 62.5 & 125 & 250 & 500 \\
\hline Urine (\% of dose) & & $57.1 \pm 11.0$ & $36.3 \pm 1.0$ & $28.5 \pm 3.4$ & $11.7 \pm 1.2$ \\
\hline Feces (\% of dose) & & $42.3 \pm 7.8$ & $66.0 \pm 1.8$ & $72.4 \pm 8.3$ & $87.3 \pm 5.5$ \\
\hline Total & & $99.4 \pm 3.4$ & $102.3 \pm 1.0$ & $100.9 \pm 5.7$ & $99.0 \pm 6.6$ \\
\hline Amounts absorbed $(\mathrm{mg} / \mathrm{kg})$ & & 35.7 & 45.4 & 71.3 & 58.5 \\
\hline
\end{tabular}

Data represent mean value \pm S.D. (rats: $n=4$, rabbits and monkeys: $n=3$ ).

Carcasses were not analyzed in rabbits and monkeys. 
Table 5. Amounts of metabolites in urine and feces after single oral administration of ${ }^{14} \mathrm{C}$-procymidone to female rats, rabbits, and monkeys at $125 \mathrm{mg} / \mathrm{kg}$

\begin{tabular}{|c|c|c|c|c|c|c|c|c|c|}
\hline \multirow{3}{*}{ Metabolite } & \multicolumn{9}{|c|}{$\%$ of dose } \\
\hline & \multicolumn{3}{|c|}{ Rat $(0-48 \mathrm{hr})^{*}$} & \multicolumn{3}{|c|}{ Rabbit $(0-48 \mathrm{hr})^{*}$} & \multicolumn{3}{|c|}{ Monkey $(0-72 \mathrm{hr})^{* *}$} \\
\hline & Urine & Feces & Total & Urine & Feces & Total & Urine & Feces & Total \\
\hline Procymidone & - & 8.1 & 8.1 & - & 15.4 & 15.4 & 0.3 & 60.7 & 61.0 \\
\hline PCM-NH-COOH & - & - & - & - & - & - & 0.1 & 0.2 & 0.4 \\
\hline PCM-COOH & 5.3 & 0.1 & 5.4 & - & - & - & \multirow{2}{*}{$3.3^{\text {a) }}$} & \multirow{2}{*}{$0.8^{\mathrm{a})}$} & \multirow{2}{*}{$4.0^{\mathrm{a})}$} \\
\hline $\mathrm{PCM}-\mathrm{CH}_{2} \mathrm{OH}$ & - & 3.6 & 3.6 & - & 0.1 & 0.1 & & & \\
\hline $\mathrm{PA}-\mathrm{CH}_{2} \mathrm{OH}(1)$ & 5.1 & 0.4 & 5.5 & - & - & - & \multirow{2}{*}{$0.5^{\mathrm{b})}$} & \multirow{2}{*}{$0.2^{\mathrm{b})}$} & \multirow{2}{*}{$0.7^{\mathrm{b})}$} \\
\hline PA-COOH (1) & 49.4 & - & 49.4 & 8.5 & - & 8.5 & & & \\
\hline $\mathrm{PA}-\mathrm{CH}_{2} \mathrm{OH}(2)$ & - & - & - & - & - & - & 0.5 & 0.1 & 0.6 \\
\hline PA-COOH (2) & - & - & - & - & - & - & 2.0 & 0.1 & 2.0 \\
\hline $\begin{array}{l}\mathrm{PCM}-\mathrm{CH}_{2} \mathrm{OH} \text {-gluc- } \\
\text { uronide }\end{array}$ & 5.5 & - & 5.5 & 71.7 & - & 71.7 & 25.6 & - & 25.6 \\
\hline Others & 2.0 & 0.4 & 2.4 & - & - & - & 0.0 & 0.1 & 0.1 \\
\hline Unextractable & - & - & - & - & - & - & - & 1.9 & 1.9 \\
\hline Total & 67.2 & 12.6 & 79.8 & 80.2 & 15.5 & 95.7 & 32.2 & 64.1 & 96.3 \\
\hline PCM & 0.0 & 8.1 & 8.1 & 0.0 & 15.4 & 15.4 & 0.4 & 60.9 & 61.3 \\
\hline Hydroxylated-PCM & 5.1 & 4.0 & 9.1 & 0.0 & 0.1 & 0.1 & $4.3^{\mathrm{c})}$ & $1.1^{\mathrm{c})}$ & $5.4^{c)}$ \\
\hline Carboxylated-PCM & 54.7 & 0.1 & 54.8 & 8.5 & 0.0 & 8.5 & $5.8^{\mathrm{d})}$ & $1.1^{\mathrm{d})}$ & $6.8^{\mathrm{d})}$ \\
\hline $\begin{array}{l}\text { Hydroxylated-PCM- } \\
\text { glucuronide }\end{array}$ & 5.5 & - & 5.5 & 71.7 & - & 71.7 & 25.6 & - & 25.6 \\
\hline
\end{tabular}

* Data were obtained from each pooled sample. ** Data represent mean value $(n=3)$.

a) PCM-COOH and PCM- $\mathrm{CH}_{2} \mathrm{OH}$ could not be separated. b) $\mathrm{PA}-\mathrm{CH}_{2} \mathrm{OH}$ (1) and PA- $\mathrm{COOH}$ (1) could not be separated. c) Data were produced by the following equation (as the worst scenario): $\mathrm{a}+\mathrm{b}+\mathrm{PA}-\mathrm{CH}_{2} \mathrm{OH}(2)$. d) Data were produced by the following equation (as the worst scenario): $\mathrm{a}+\mathrm{b}+\mathrm{PA}-$ $\mathrm{COOH}(2)$

-: Not determined.

strated that the AUC of PCM in monkeys at a non-teratogenic dose level was larger than that in rats at the lowest teratogenic dose level $(37.5 \mathrm{mg} / \mathrm{kg})$.

The major components in the plasma of rats were PCM and Hydroxylated-PCM. Hydroxylated-PCM-glucuronide was a major component in rabbit plasma. In monkeys, the major component in plasma was PCM (Supplemental Tables S1-S3).

The amounts absorbed from the gastrointestinal tract in rabbits were similar to those in rats. In monkeys administered ${ }^{14} \mathrm{C}$ procymidone at $125 \mathrm{mg} / \mathrm{kg}$, the dose level used in a previous teratogenicity study, values were similar to those in rats administered ${ }^{14} \mathrm{C}$-procymidone at $37.5 \mathrm{mg} / \mathrm{kg}$ (the lowest teratogenic dose) (Table 4).

In all species, the primary fecal component was PCM. In rats, Carboxylated-PCM was a major urinary component. In contrast, Hydroxylated-PCM-glucuronide was a major component in rabbit and monkey urine, but only a minor component in rat urine (Table 5, Supplemental Tables S4 and S5).

\section{Repeated-administration pharmacokinetic and excretion studies}

Hydroxylated-PCM was found to be the major component in the plasma of rats; however, the major component in the plasma of monkeys was PCM (Supplemental Tables S6-S8). In both species, the major fecal component was PCM. In rats, Carbox-
ylated-PCM was a major urinary metabolite. The metabolic profile in the rat repeated-administration study was similar to that in the single-administration study. In monkeys, Hydroxylated-PCM and Hydroxylated-PCM-glucuronide were major urinary metabolites (Table 6, Supplemental Tables S9 and S10). Although the metabolic profile in urine in the monkey repeated-administration study was partially different from that in the single-administration study, the difference observed in the repeated-administration study was related to Hydroxylated-PCM, which was produced via the deconjugation of HydroxylatedPCM-glucuronide by contact with $\beta$-glucuronidase in intestinal bacteria due to insufficient washing of metabolic cages. Indeed, this tendency was observed remarkably in the lower-dose group. It was caused by the fact that absolute amounts of HydroxylatedPCM-glucuronide excreted into urine in the lower-dose group were smaller than those in the higher-dose group, and, consequently, it seemed that glucuronides in the lower-dose group were easily deconjugated by $\beta$-glucuronidase in intestinal bacteria. Therefore, it was reasonable that the sum of the amounts of Hydroxylated-PCM and Hydroxylated-PCM-glucuronide should be used in comparison between repeated- and singleadministration studies. Based on this comparison, no marked difference in metabolic profiles was observed between repeatedand single-administration studies in monkeys.

In rats, the ${ }^{14} \mathrm{C}$ levels in plasma reached the steady-state level 
Table 6. Amounts of metabolites in urine and feces after repeated oral administration of ${ }^{14} \mathrm{C}$-procymidone to female rats and monkeys at $125 \mathrm{mg} / \mathrm{kg} / \mathrm{day}$

\begin{tabular}{|c|c|c|c|c|c|c|}
\hline \multirow{3}{*}{ Metabolite } & \multicolumn{6}{|c|}{$\%$ of dose* } \\
\hline & \multicolumn{3}{|c|}{ Rats** } & \multicolumn{3}{|c|}{ Monkeys*** } \\
\hline & Urine & Feces & Total & Urine & Feces & Total \\
\hline Procymidone & - & 5.3 & 5.3 & 0.3 & 65.2 & 65.5 \\
\hline PCM-NH-COOH & - & - & - & 0.3 & 0.5 & 0.8 \\
\hline PCM-COOH & 14.8 & 0.5 & 15.3 & \multirow{2}{*}{$4.5^{\mathrm{a})}$} & \multirow{2}{*}{$1.5^{\mathrm{a})}$} & \multirow{2}{*}{$6.0^{\text {a) }}$} \\
\hline $\mathrm{PCM}-\mathrm{CH}_{2} \mathrm{OH}$ & - & 0.6 & 0.6 & & & \\
\hline $\mathrm{PA}-\mathrm{CH}_{2} \mathrm{OH}(1)$ & 2.7 & 0.2 & 2.9 & \multirow{2}{*}{$2.3^{\mathrm{b})}$} & \multirow{2}{*}{$0.4^{\mathrm{b})}$} & \multirow{2}{*}{$2.7^{\mathrm{b})}$} \\
\hline $\mathrm{PA}-\mathrm{COOH}(1)$ & 51.8 & - & 51.8 & & & \\
\hline $\mathrm{PA}-\mathrm{CH}_{2} \mathrm{OH}(2)$ & - & - & - & 8.6 & 0.4 & 9.0 \\
\hline $\mathrm{PA}-\mathrm{COOH}(2)$ & - & - & - & 1.6 & 0.1 & 1.8 \\
\hline PCM- $\mathrm{CH}_{2} \mathrm{OH}$-glucuronide & 4.6 & - & 4.6 & 7.7 & 0.2 & 7.9 \\
\hline Others & 0.9 & 0.6 & 1.5 & 0.1 & 0.1 & 0.2 \\
\hline Unextractable & - & 8.3 & 8.3 & - & 1.3 & 1.3 \\
\hline Total & 74.7 & 15.5 & 90.2 & 25.3 & 69.8 & 95.1 \\
\hline PCM & 0.0 & 5.3 & 5.3 & 0.5 & 65.7 & 66.2 \\
\hline Hydroxylated-PCM & 2.7 & 0.8 & 3.5 & $15.4^{\mathrm{c})}$ & $2.3^{\mathrm{c})}$ & $17.7^{\mathrm{c})}$ \\
\hline Carboxylated-PCM & 66.6 & 0.5 & 67.1 & $8.4^{\mathrm{d})}$ & $2.0^{\mathrm{d})}$ & $10.5^{\mathrm{d})}$ \\
\hline Hydroxylated-PCM-glucuronide & 4.6 & 0.0 & 4.6 & 7.7 & 0.2 & 7.9 \\
\hline
\end{tabular}

* Data were obtained from excreta within $24 \mathrm{hr}$ after 14 th administration. $* *$ Data were obtained from each pooled sample. *** Data represent mean value $(n=3)$.

a) PCM-COOH and PCM-CH $-\mathrm{OH}$ could not be separated. b) $\mathrm{PA}-\mathrm{CH}_{2} \mathrm{OH}$ (1) and PA-COOH (1) could not be separated. c) Data were produced by the following equation (as the worst scenario): $a+b+P A-\mathrm{CH}_{2} \mathrm{OH}(2)$. d) Data were produced by the following equation (as the worst scenario): $a+b+\mathrm{PA}-$ $\mathrm{COOH}(2)$. - : Not determined.
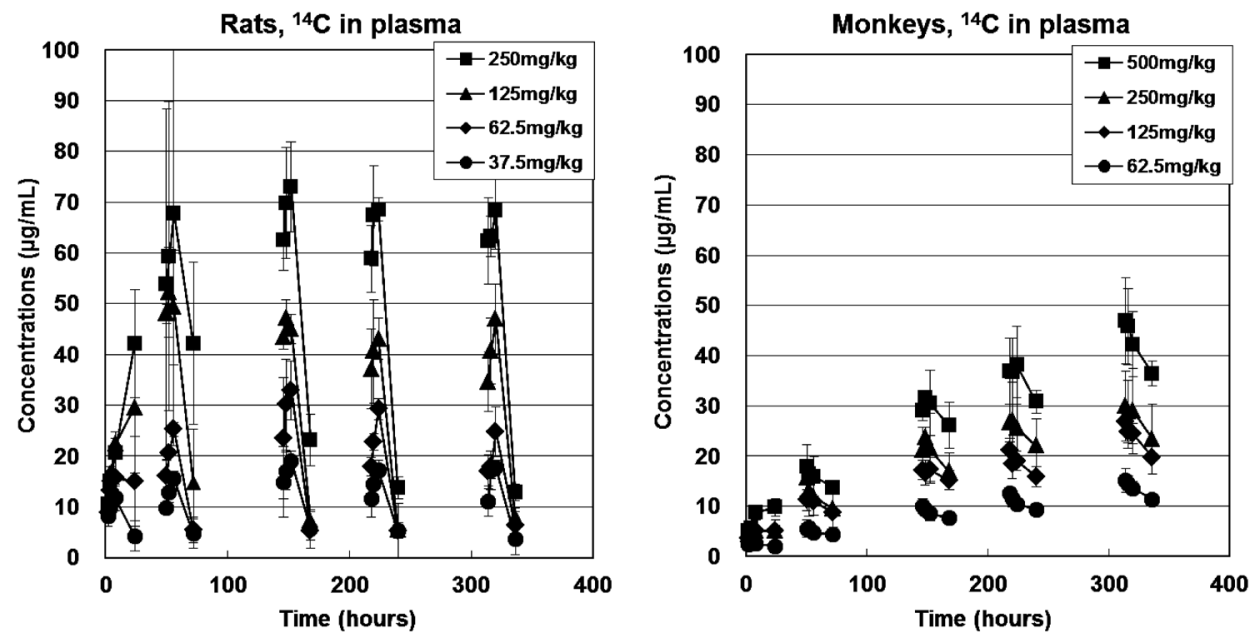

Fig. 2. Concentrations of ${ }^{14} \mathrm{C}$ in plasma during and after repeated oral administration of ${ }^{14} \mathrm{C}$-procymidone for 14 days to female rats and monkeys. Points and bars are mean and S.D. (Rats: $n=4$, Monkeys: $n=3$ ).

approximately 3 days after the first administration. In monkeys, the ${ }^{14} \mathrm{C}$ levels in plasma increased in direct proportion to the administration frequency (Fig. 2). The PCM concentration in rat plasma showed a decreasing trend with the number of administration (Fig. 3). In contrast, the internal exposure levels of PCM in monkeys remained relatively stable (Fig. 3). Therefore, following repeated administrations, PCM concentrations in monkeys at a non-teratogenic dose level of $125 \mathrm{mg} / \mathrm{kg} /$ day were much higher than those in rats at teratogenic dose levels. Based on plasma concentrations, the $C_{\max }$ and $A U C$, the internal concentration of PCM was similar between monkeys and rats orally dosed at $125 \mathrm{mg} / \mathrm{kg} /$ day (Fig. 3). The $C_{\max }$ and $A U C_{2-24}$ of Hydroxylated-PCM in rat plasma were 4-15 times and 6-16 times larger, respectively, than those in monkey plasma (Fig. 4). Also, concentrations of Hydroxylated-PCM were several times higher than those of PCM in rat plasma. 

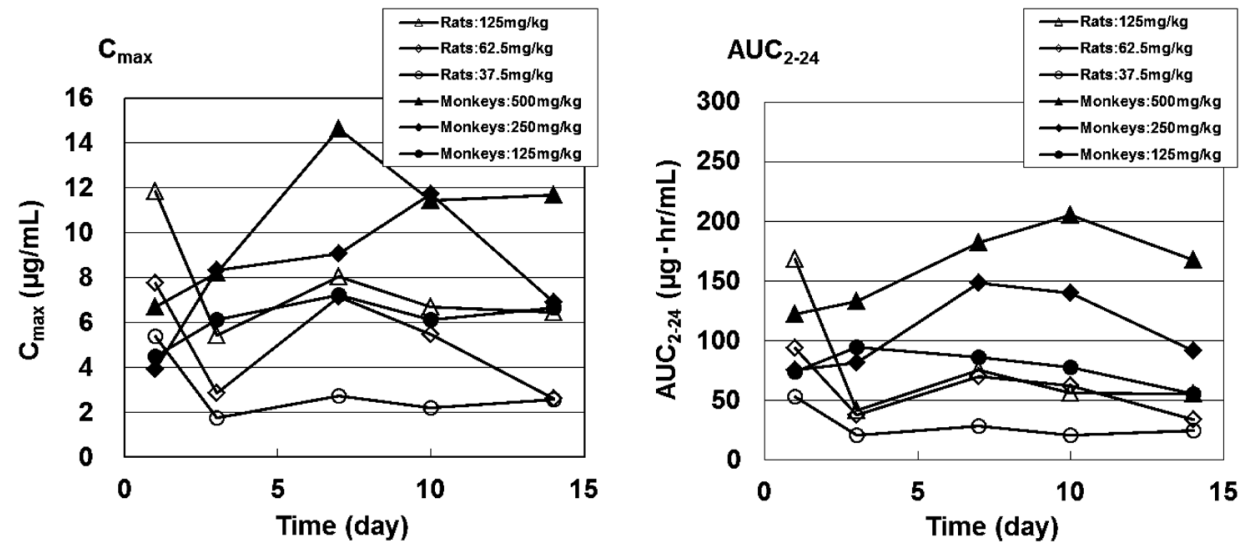

Fig. 3. $C_{\max }$ and $A U C_{2-24}$ values for PCM in plasma during and after repeated oral administration of ${ }^{14} \mathrm{C}$-procymidone for 14 days to female rats and monkeys.
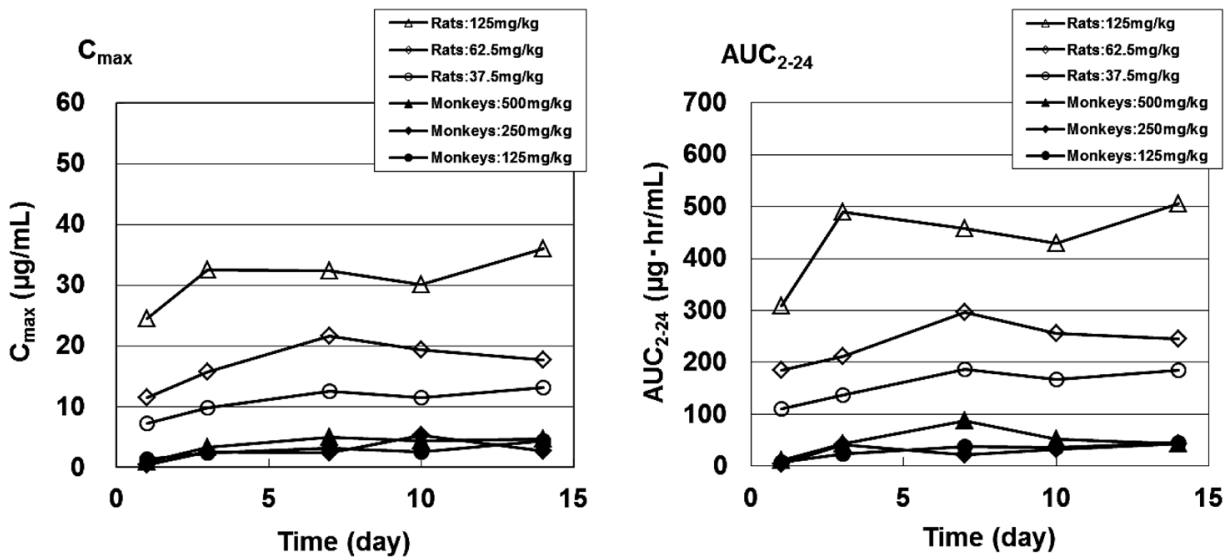

Fig. 4. $C_{\max }$ and $A U C_{2-24}$ values for Hydroxylated-PCM in plasma during and after repeated oral administration of ${ }^{14} \mathrm{C}$-procymidone for 14 days to female rats and monkeys.

Table 7. Cumulative ${ }^{14} \mathrm{C}$-recoveries in urine and feces within $120 \mathrm{hr}$ (rats) or $72 \mathrm{hr}$ (monkeys) after repeated oral administration of ${ }^{14} \mathrm{C}$-procymidone to female rats and monkeys and the amounts absorbed from the gastrointestinal tract

\begin{tabular}{|c|c|c|c|c|}
\hline \multirow{2}{*}{ Rats } & \multicolumn{4}{|c|}{ Dose (mg/kg/day) } \\
\hline & 37.5 & 62.5 & 125 & 250 \\
\hline Urine (\% of dose) & $80.5 \pm 2.8$ & $76.9 \pm 1.7$ & $79.1 \pm 2.3$ & $60.9 \pm 2.3$ \\
\hline Feces (\% of dose) & $14.6 \pm 2.5$ & $18.4 \pm 2.4$ & $16.2 \pm 2.5$ & $34.7 \pm 1.4$ \\
\hline Carcass ( $\%$ of dose) & $0.3 \pm 0.1$ & $0.2 \pm 0.1$ & $0.2 \pm 0.1$ & $0.1 \pm 0.1$ \\
\hline Total & $95.4 \pm 0.3$ & $95.4 \pm 0.9$ & $95.4 \pm 1.1$ & $95.7 \pm 1.4$ \\
\hline Amounts absorbed $(\mathrm{mg} / \mathrm{kg})$ & 30.2 & 48.1 & 98.9 & 152.3 \\
\hline \multirow{2}{*}{ Monkeys } & \multicolumn{4}{|c|}{ Dose (mg/kg/day) } \\
\hline & 62.5 & 125 & 250 & 500 \\
\hline Urine (\% of dose) & $38.6 \pm 0.5$ & $25.3 \pm 3.4$ & $19.1 \pm 2.6$ & $17.8 \pm 1.6$ \\
\hline Feces (\% of dose) & $55.0 \pm 3.0$ & $69.8 \pm 1.6$ & $72.1 \pm 4.8$ & $78.1 \pm 1.8$ \\
\hline Total & $93.6 \pm 3.5$ & $95.1 \pm 1.8$ & $91.2 \pm 2.6$ & $96.0 \pm 2.9$ \\
\hline Amounts absorbed $(\mathrm{mg} / \mathrm{kg})$ & 24.1 & 31.7 & 47.8 & 89.2 \\
\hline
\end{tabular}

Data represent mean value \pm S.D. (rats: $n=4$, monkeys: $n=3$ ).

Carcasses were not analyzed in monkeys. 
Table 8. Cumulative ${ }^{14} \mathrm{C}$-excretion in bile, urine and feces and ${ }^{14} \mathrm{C}$ in gastrointestinal contents and carcass after single oral administration of ${ }^{14} \mathrm{C}$-procymidone to female bile-duct cannulated rats, rabbit and monkey $(0-48 \mathrm{hr})$

\begin{tabular}{|c|c|c|c|c|}
\hline \multirow{3}{*}{ Matrix } & \multicolumn{4}{|c|}{$\%$ of dose } \\
\hline & \multicolumn{2}{|c|}{ Rats* } & \multirow{2}{*}{$\begin{array}{c}\text { Rabbit** } \\
125 \mathrm{mg} / \mathrm{kg}\end{array}$} & \multirow{2}{*}{$\begin{array}{c}\text { Monkey** } \\
125 \mathrm{mg} / \mathrm{kg}\end{array}$} \\
\hline & $3.5 \mathrm{mg} / \mathrm{kg}$ & $62.5 \mathrm{mg} / \mathrm{kg}$ & & \\
\hline Bile & $12.0 \pm 5.9$ & $19.3 \pm 7.9$ & 1.2 & 6.0 \\
\hline Urine & $70.6 \pm 7.7$ & $58.6 \pm 5.8$ & 24.2 & 15.5 \\
\hline Feces & $10.1 \pm 2.8$ & $6.7 \pm 4.3$ & 3.5 & 0.1 \\
\hline Gastrointestinal contents & $0.6 \pm 0.9$ & $3.7 \pm 4.9$ & 49.3 & 53.2 \\
\hline Carcass & $2.6 \pm 1.4$ & $7.1 \pm 1.8$ & - & - \\
\hline Total & $95.9 \pm 1.6$ & $95.3 \pm 0.3$ & 78.2 & 74.7 \\
\hline
\end{tabular}

* Data represent mean value \pm S.D. $(n=4)$.** Data were obtained from one animal. —: Not analyzed.

Table 9. Amounts of metabolites in bile, urine and feces after single oral administration of ${ }^{14} \mathrm{C}$-procymidone to female rats, rabbit, and monkey $(0-48 \mathrm{hr})$

\begin{tabular}{|c|c|c|c|c|c|c|c|c|c|c|c|c|c|c|c|c|}
\hline \multirow{3}{*}{ Metabolite } & \multicolumn{16}{|c|}{$\%$ of dose } \\
\hline & \multicolumn{4}{|c|}{ Rats, $3.5 \mathrm{mg} / \mathrm{kg}^{*}$} & \multicolumn{4}{|c|}{ Rats, $62.5 \mathrm{mg} / \mathrm{kg}^{*}$} & \multicolumn{4}{|c|}{ Rabbit, $125 \mathrm{mg} / \mathrm{kg} * *$} & \multicolumn{4}{|c|}{ Monkey, $125 \mathrm{mg} / \mathrm{kg}^{* *}$} \\
\hline & Bile & Urine & Feces & Total & Bile & Urine & Feces & Total & Bile & Urine & Feces & Total & Bile & Urine & Feces & Total \\
\hline Procymidone & - & - & 4.4 & 4.4 & - & - & 3.8 & 3.8 & 0.0 & 0.0 & 0.1 & 0.1 & 0.0 & 0.0 & 0.0 & 0.0 \\
\hline PCM-NH-COOH & - & - & - & 0.0 & - & - & - & 0.0 & 0.0 & 0.0 & 0.0 & 0.0 & 0.0 & 0.0 & 0.0 & 0.0 \\
\hline PCM-COOH & - & 36.9 & 0.2 & 37.1 & - & 28.4 & 0.1 & 28.5 & $0.0^{\mathrm{a})}$ & $2.2^{\text {a) }}$ & $1.3^{\mathrm{a})}$ & $3.5^{\text {a) }}$ & $0.1^{\text {a) }}$ & $1.1^{\text {a) }}$ & $0.0^{\mathrm{a})}$ & $1.2^{\mathrm{a})}$ \\
\hline $\mathrm{PCM}-\mathrm{CH}_{2} \mathrm{OH}$ & - & - & 1.3 & 1.3 & - & - & 1.1 & 1.1 & & & & & & & & \\
\hline $\mathrm{PA}-\mathrm{CH}_{2} \mathrm{OH}(1)$ & - & 2.4 & - & 2.4 & - & 3.0 & - & 3.0 & (b) & $5^{\text {b) }}$ & $0^{\mathrm{b}}$ ) & $0^{6} 6^{\mathrm{b}}$ & $0^{\mathrm{b})}$ & $\left(1^{\mathrm{b})}\right.$ & $0^{\mathrm{b})}$ & $0^{\mathrm{b})}$ \\
\hline $\mathrm{PA}-\mathrm{COOH}(1)$ & 0.4 & 25.0 & - & 25.4 & 0.5 & 20.9 & - & 21.4 & 0.0 & .0 & 0.0 & 0.0 & 0.0 & 0.1 & 0.0 & 0.1 \\
\hline $\mathrm{PA}-\mathrm{CH}_{2} \mathrm{OH}(2)$ & - & - & - & 0.0 & - & - & - & 0.0 & 0.0 & 0.0 & 0.0 & 0.1 & 0.0 & 0.0 & 0.0 & 0.1 \\
\hline $\mathrm{PA}-\mathrm{COOH}(2)$ & - & - & - & 0.0 & - & - & - & 0.0 & 0.0 & 1.4 & 0.0 & 1.4 & 0.1 & 0.4 & 0.0 & 0.4 \\
\hline PCM- $\mathrm{CH}_{2} \mathrm{OH}$-glucuronide & 11.6 & 3.7 & - & 15.3 & 18.8 & 4.0 & - & 22.8 & 1.1 & 20.0 & 0.3 & 21.4 & 5.7 & 13.8 & 0.0 & 19.5 \\
\hline Others & - & 2.5 & - & 2.5 & - & 2.4 & - & 2.4 & 0.0 & 0.0 & 0.0 & 0.0 & 0.0 & 0.0 & 0.0 & 0.0 \\
\hline Unextractable & - & - & 4.2 & 4.2 & - & - & 1.6 & 1.6 & - & - & 1.7 & 1.7 & - & - & 0.1 & 0.1 \\
\hline Total & 12.0 & 70.6 & 10.1 & 92.7 & 19.3 & 58.6 & 6.7 & 84.6 & 1.2 & 24.2 & 3.5 & 28.8 & 6.0 & 15.5 & 0.1 & 21.5 \\
\hline PCM & 0.0 & 0.0 & 4.4 & 4.4 & 0.0 & 0.0 & 3.8 & 3.8 & 0.0 & 0.1 & 0.1 & 0.2 & 0.0 & 0.0 & 0.0 & 0.1 \\
\hline Hydroxylated-PCM & 0.0 & 2.4 & 1.3 & 3.7 & 0.0 & 3.0 & 1.1 & 4.1 & $0.1^{c)}$ & $2.7^{c)}$ & $1.4^{\mathrm{c})}$ & $4.2^{\mathrm{c})}$ & $0.2^{\mathrm{c})}$ & $1.2^{\mathrm{c})}$ & $0.0^{c)}$ & $1.4^{\mathrm{c})}$ \\
\hline Carboxylated-PCM & 0.4 & 61.9 & 0.2 & 62.5 & 0.5 & 49.3 & 0.1 & 49.9 & $0.1^{\mathrm{d})}$ & $4.1^{\mathrm{d})}$ & $1.4^{\mathrm{d})}$ & $5.5^{\mathrm{d})}$ & $0.2^{\mathrm{d})}$ & $1.5^{\mathrm{d})}$ & $0.0^{\mathrm{d})}$ & $1.8^{\mathrm{d})}$ \\
\hline $\begin{array}{l}\text { Hydroxylated-PCM-gluc- } \\
\text { uronide }\end{array}$ & 11.6 & 3.7 & - & 15.3 & 18.8 & 4.0 & - & 22.8 & 1.1 & 20.0 & 0.3 & 21.4 & 5.7 & 13.8 & 0.0 & 19.5 \\
\hline
\end{tabular}

* Data were obtained from each pooled sample. **: Data were obtained from one animal.

a) PCM-COOH and PCM- $\mathrm{CH}_{2} \mathrm{OH}$ could not be separated. b) $\mathrm{PA}-\mathrm{CH}_{2} \mathrm{OH}$ (1) and PA-COOH (1) could not be separated. c) Data were produced by the following equation (as the worst scenario): $a+b+P A-\mathrm{CH}_{2} \mathrm{OH}$ (2). d) Data were produced by the following equation (as the worst scenario): $\mathrm{a}+\mathrm{b}+\mathrm{PA}-$ $\mathrm{COOH}(2)$. - : Not determined.

As shown in Table 7, in monkeys administered with ${ }^{14} \mathrm{C}$ procymidone at $125 \mathrm{mg} / \mathrm{kg}$, the amounts absorbed $(\mathrm{mg} / \mathrm{kg}$ ) were similar to those in rats administered with ${ }^{14} \mathrm{C}$-procymidone at $37.5 \mathrm{mg} / \mathrm{kg}$.

3. Biliary excretion of procymidone in rats, rabbits, and monkeys As shown in Table 8, in rats at doses of $62.5 \mathrm{mg} / \mathrm{kg}$, the ${ }^{14} \mathrm{C}$ excretion in bile accounted for $19.3 \%$ of the dose within $48 \mathrm{hr}$ after administration. Hydroxylated-PCM-glucuronide was mainly detected in the bile, accounting for $18.8 \%$ of the administered dose (more than $97 \%$ of the bile sample) at $62.5 \mathrm{mg} / \mathrm{kg}$. Hydroxylat-
ed-PCM-glucuronide in urine was $4.0 \%$ of the dose at $62.5 \mathrm{mg} /$ $\mathrm{kg}$ (Table 9). The excretion profiles at a dose of $3.5 \mathrm{mg} / \mathrm{kg}$ were similar to those at $62.5 \mathrm{mg} / \mathrm{kg}$. The ${ }^{14} \mathrm{C}$ excretion in rabbit and monkey bile was $1.2 \%$ and $6.0 \%$ of the dose within $48 \mathrm{hr}$ after administration, respectively (Table 8). Hydroxylated-PCM-glucuronide was detected in rabbit and monkey bile, accounting for $1.1 \%$ and $5.7 \%$ of the administered dose (more than $97 \%$ and $95 \%$ of the bile sample), respectively, at $125 \mathrm{mg} / \mathrm{kg}$. The major metabolite in rabbit and monkey urine was Hydroxylated-PCMglucuronide (20.0\% and $13.8 \%$ of the dose, respectively) (Table 9). PCM was the major component of metabolites in feces and 

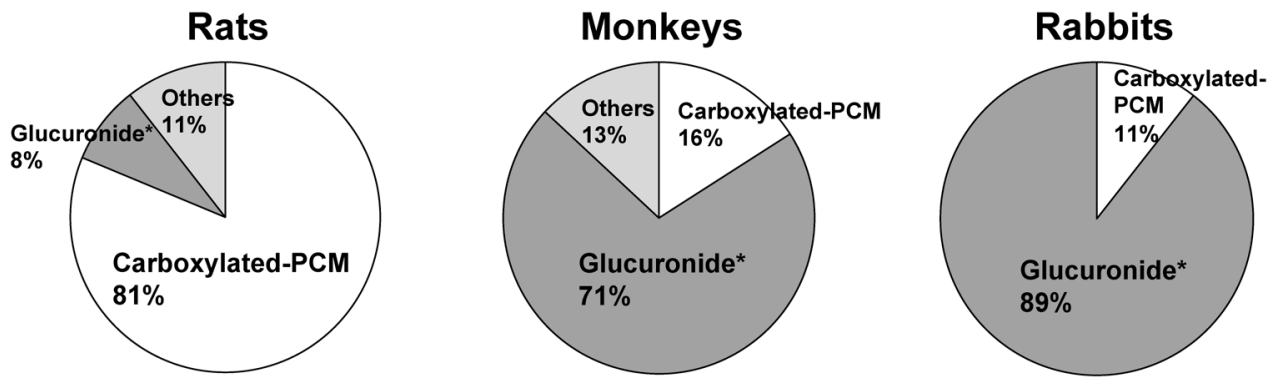

Glucuronide*: Hydroxylated-PCM-glucuronide

Fig. 5. Metabolites in urine after a single oral administration of ${ }^{14} \mathrm{C}$-procymidone to female rats, rabbits, and monkeys. Data were obtained from $125 \mathrm{mg} /$ $\mathrm{kg}$ dose groups.
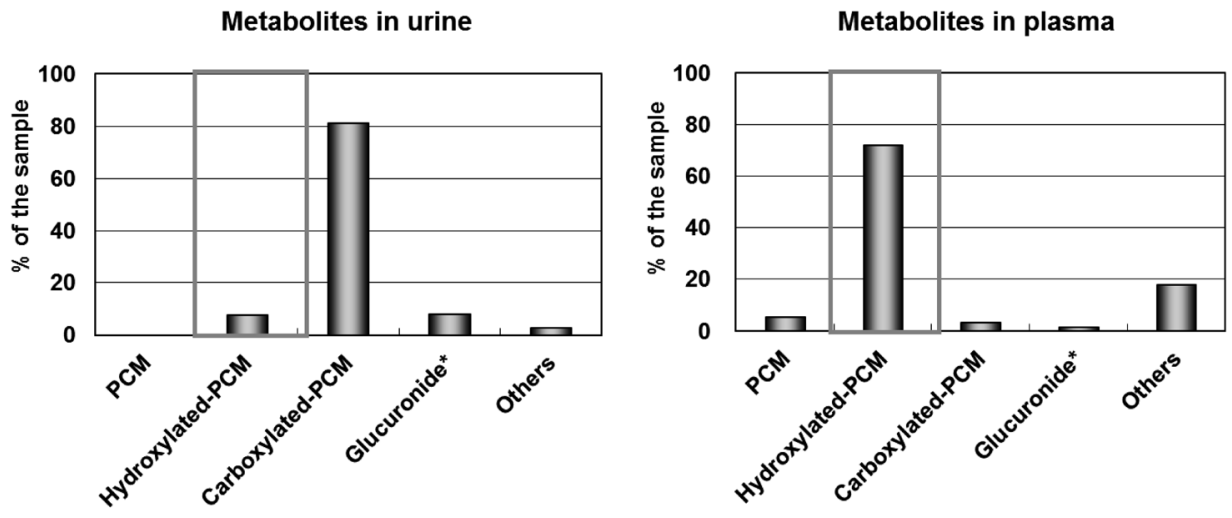

Glucuronide*: Hydroxylated-PCM-glucuronide

Fig. 6. Metabolites in urine and plasma after a single oral administration of ${ }^{14} \mathrm{C}$-procymidone to female rats. Data were obtained from $125 \mathrm{mg} / \mathrm{kg}$ dose groups.

Rats (threshold MW: 325)

Rabbits (threshold MW: 475)

Monkeys (threshold MW: 475)

Humans (threshold MW: 500)

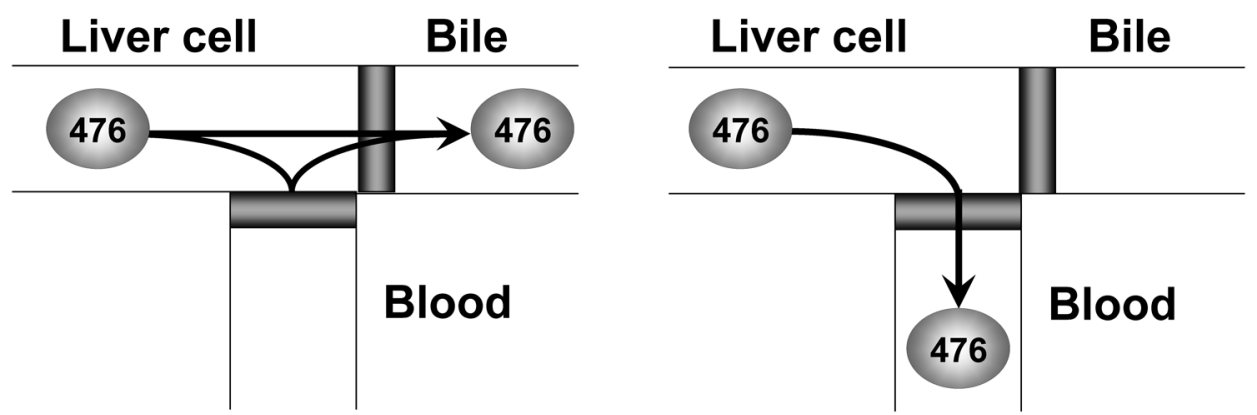

Hydroxylated-PCM-glucuronide: MW; 476

Fig. 7. Species differences in biliary excretion of the glucuronide of Hydroxylated-PCM. 
Table 10. Excretion ratio of Hydroxylated-PCM-glucuronide to bile

\begin{tabular}{|c|c|c|c|c|}
\hline & \multicolumn{2}{|c|}{ Rats } & \multirow{2}{*}{$\begin{array}{c}\text { Rabbit } \\
125 \mathrm{mg} / \mathrm{kg}\end{array}$} & \multirow{2}{*}{$\begin{array}{c}\text { Monkey } \\
125 \mathrm{mg} / \mathrm{kg} \\
\end{array}$} \\
\hline & $3.5 \mathrm{mg} / \mathrm{kg}$ & $62.5 \mathrm{mg} / \mathrm{kg}$ & & \\
\hline Biliary excretion ratio* & 3.14 & 4.70 & 0.06 & 0.41 \\
\hline
\end{tabular}

* Data were obtained from the following equation: Biliary excretion ratio=biliary excretion rate (\% of dose)/urinary excretion rate (\% of dose).

intestinal contents.

\section{Discussion}

In teratogenicity studies, developmental toxicity (abnormalities of external genitalia in male rats) was observed in rats but not in rabbits or monkeys. The lack of apparent toxic observations in rabbit and monkey studies was thought to be explained by their lower internal exposure to procymidone as compared to rats. If higher internal exposure could be achieved, developmental toxicity might possibly be observed even in rabbits and monkeys. In response to these concerns, we have carried out a series of studies to determine whether there are differences in internal doses among rats, rabbits, and monkeys. Furthermore, we have conducted a series of mechanistic studies to determine whether there are species differences in metabolism, excretion, placental transfer, and protein binding among rats, rabbits, monkeys, and humans.

In the present investigation, the pharmacokinetics and excretion of procymidone in female rats, rabbits, and monkeys were clarified. In the single-administration pharmacokinetic and excretion studies, the $C_{\max }$ of ${ }^{14} \mathrm{C}$ in rabbits administered with ${ }^{14} \mathrm{C}$ procymidone and the amounts absorbed from the gastrointestinal tracts at each dose were similar to those in rats. In rabbits, however, the $A U C_{0-120}$ and $A U C_{0-\infty}$ of ${ }^{14} \mathrm{C}$ in plasma were much lower than those in rats, indicating that the metabolism and excretion of ${ }^{14} \mathrm{C}$-procymidone in rabbits are much faster than in rats. PCM concentrations in rats were higher than in rabbits and monkeys following a single oral administration. The $C_{\max }$ of PCM in monkeys at a non-teratogenic dose level of $125 \mathrm{mg} / \mathrm{kg} /$ day was lower than that in rats at teratogenic dose levels. However, the $A U C_{0-120}$ and $A U C_{0-\infty}$ of PCM in monkey plasma at $125 \mathrm{mg} / \mathrm{kg}$ were similar to those in rats at $62.5 \mathrm{mg} / \mathrm{kg}$. Therefore, it was demonstrated that the AUC of PCM in monkeys at a nonteratogenic dose level was larger than that in rats at the lowest teratogenic dose level $(37.5 \mathrm{mg} / \mathrm{kg})$.

In teratogenicity studies, maternal rats are generally dosed repeatedly. Treatment starts during early organogenesis and throughout the potential period of development of abnormal external genitalia. Therefore, repeated-administration pharmacokinetic studies are more relevant to procymidone teratology because the dosing regime is the same. In the repeated-administration studies, the differences between rats and monkeys were reduced because the internal exposure levels increased with the number of administrations in monkeys; thus, monkeys were comparable to rats in this regard. Also, it is possible that induction of metabolic enzymes might occur with repeated oral administration of procymidone in rats (hypermetabo- lism). The $A U C_{2-24}$ of ${ }^{14} \mathrm{C}$ and PCM in monkeys administered with ${ }^{14} \mathrm{C}$-procymidone at $125 \mathrm{mg} / \mathrm{kg}$ were nearly equal to those in rats administered with ${ }^{14} \mathrm{C}$-procymidone at $62.5 \mathrm{mg} / \mathrm{kg}$, and the amounts absorbed from the gastrointestinal tracts in monkeys administered with ${ }^{14} \mathrm{C}$-procymidone at $125 \mathrm{mg} / \mathrm{kg}$ were nearly equal to those in rats administered with ${ }^{14} \mathrm{C}$-procymidone at $37.5 \mathrm{mg} / \mathrm{kg}$. Therefore, PCM concentrations in monkeys at a non-teratogenic dose level of $125 \mathrm{mg} / \mathrm{kg} /$ day were much higher than those in rats at teratogenic dose levels, following repeated administration.

From these results, it was concluded that procymidone itself (PCM) and/or total $\left({ }^{14} \mathrm{C}\right)$ of procymidone and its metabolites were not direct causes of the developmental toxicity. Because it was thought that the cause of developmental toxicity is related to anti-androgenic action, we previously conducted a study of anti-androgen assay. In the previous study, ${ }^{9)}$ we demonstrated that there were no species differences for binding to androgen receptors, and only PCM and Hydroxylated-PCM, being approximately half of the PCM level, had anti-androgenic activities, and other metabolites (Carboxylated-PCM and Hydroxylated-PCM-glucuronide) had no anti-androgenic activity. Based on the above findings, it was speculated that the apparent toxic observations in rats were distinguished from the absence of toxicity in rabbits and monkeys by higher internal exposure of its metabolite with anti-androgenic characteristics, HydroxylatedPCM, not procymidone (PCM). In the present studies, remarkable species differences in plasma concentrations of Hydroxylated-PCM were observed. All data showed that the concentration and the $A U C$ in rat plasma were much higher than those in rabbit and monkey plasma. Furthermore, the Hydroxylated-PCM concentration was much higher than the PCM concentration in rat plasma. Therefore, it was considered that Hydroxylated-PCM could be a key factor in the observed species differences in developmental toxicity between rats and monkeys.

In an analysis of metabolites in urine obtained from singleadministration pharmacokinetic and excretion studies, it was observed that Hydroxylated-PCM-glucuronide is a major metabolite in the urine of monkeys and rabbits but only a minor metabolite in rat urine (Fig. 5). The difference in excretion of Hydroxylated-PCM-glucuronide into urine was thought to be related to the higher Hydroxylated-PCM plasma concentration in rats. Furthermore, although the major metabolite in rat plasma was Hydroxylated-PCM, it was not significant in rat urine (Fig. 6). Therefore, Hydroxylated-PCM is considered to be reabsorbed in the kidney due to its lipophilicity, and biotransformation from Hydroxylated-PCM to Carboxylated-PCM is very slow. The difference in urinary excretion of Hydroxylated-PCM- 


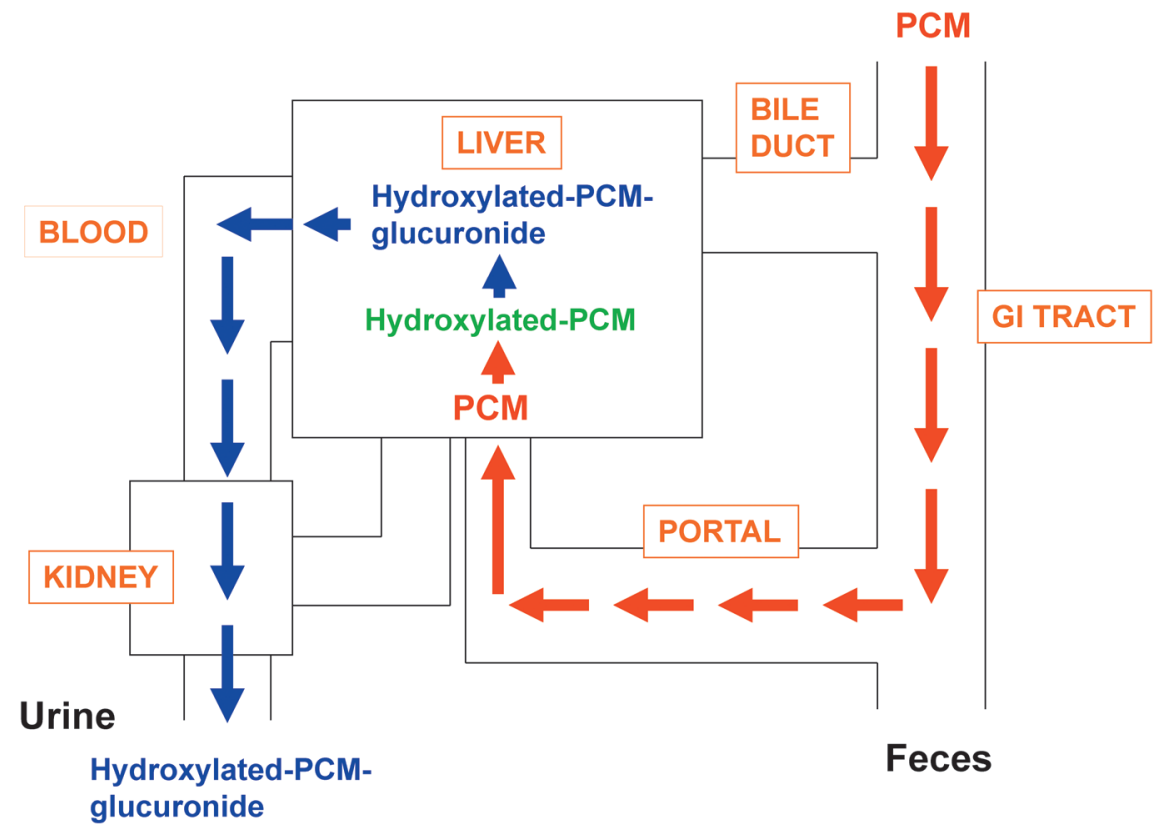

Fig. 8. Flow diagrams of procymidone and its metabolites in rabbits and monkeys. (Simple excretion: rapid urinary excretion.) Thick arrows show main pathways.

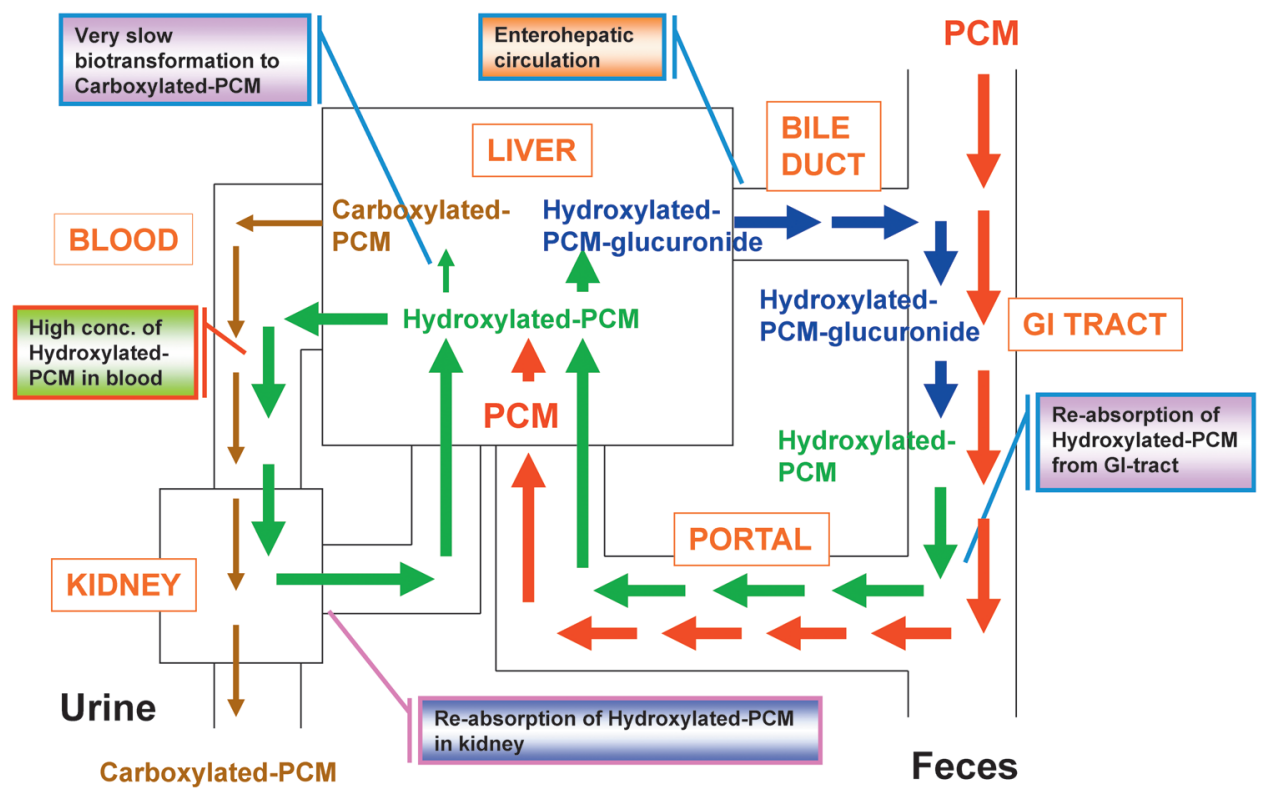

Fig. 9. Flow diagrams of procymidone and its metabolites in rats. (Complex excretion: biliary excretion and enterohepatic circulation.) Thick arrows show main pathways.

glucuronide appears to be due to a species difference in its biliary excretion, as reported extensively in the literature. ${ }^{10-12)}$ The difference might be derived from species differences in transporters in the liver. ${ }^{13-16)}$ The glucuronic acid conjugate, Hydroxylated-PCM-glucuronide, has a molecular weight (MW) of 476 , which means that it should pass more readily into the bloodstream in rabbits, monkeys, and humans than in rats (Fig. 7). ${ }^{17)}$ It follows that the biliary excretion rate is higher in rats and that urinary excretion predominates in the other species. Based on this hypothesis, biliary excretion experiments have been conducted in the present study. As described above, the biliary excretion rate of Hydroxylated-PCM-glucuronide was much higher in rats than in rabbits and monkeys. As shown in Table 10, the biliary excretion ratio [biliary excretion rate (\% of the dose)/ urinary excretion rate (\% of the dose)] of Hydroxylated-PCMglucuronide in rats was 78 times higher than that in rabbits and 12 times higher than that in monkeys.

In an extensive series of studies, the following conclusions 
were obtained regarding species differences in the developmental toxicity of procymidone: in rabbits and monkeys, procymidone is absorbed from the gastrointestinal tract into the liver via the portal vein, where it is hydroxylated (HydroxylatedPCM) and transformed into a glucuronic acid conjugate (Hydroxylated-PCM-glucuronide), which in turn is transferred to the blood circulation and rapidly excreted in urine (Fig. 8). On the other hand, in rats, after glucuronidation of HydroxylatedPCM, the glucuronide (Hydroxylated-PCM-glucuronide) is excreted into the bile, deconjugated in the gastrointestinal tract, and reabsorbed, resulting in enterohepatic circulation (Fig. 9). This can be considered important because it results in sustained high plasma concentrations of Hydroxylated-PCM. Therefore, the species differences in the developmental toxicity of procymidone are mainly caused by species differences of HydroxylatedPCM concentrations in plasma (retention of Hydroxylated-PCM in the animal body), and these differences can be attributed to variation in the biliary excretion rate of the glucuronic acid conjugate (Hydroxylated-PCM-glucuronide). As mentioned above, as the threshold of biliary excretion in humans is similar to that in rabbits and monkeys, the possibility of teratogenicity of procymidone in humans is considered to be very low. To confirm this hypothesis, further studies are needed.

\section{References}

1) Y. Hisada, K. Maeda, N. Tottori and Y. Kawase: J. Pestic. Sci. 1, 145149 (1976).

2) Y. Hisada, K. Maeda, Y. Kawase and J. Miyamoto: J. Pestic. Sci. 1, 201-206 (1976).

3) Y. Hisada, T. Kato and Y. Kawase: Neth. J. Plant Pathol. 83(S1), 71-78
(1977).

4) N. Mikami, H. Satogami and J. Miyamoto: J. Pestic. Sci. 4, 165-174 (1979).

5) K. Shiba, H. Kaneko, H. Yoshino, N. Kakuta, K. Iba, I. Nakatsuka, A. Yoshitake, H. Yamada and J. Miyamoto: J. Pestic. Sci. 16, 27-33 (1991).

6) H. Nagahori, M. Matsui, Y. Tomigahara, H. Matsunaga, H. Kaneko and I. Nakatsuka: J. Pestic. Sci. 22, 293-298 (1997).

7) H. Tarui, J. Abe, Y. Tomigahara, S. Kawamura and H. Kaneko: J. Agric. Food Chem. 57, 10883-10888 (2009).

8) S. Hosokawa, M. Murakami, M. Ineyama, T. Yamada, A. Yoshitake, H. Yamada and J. Miyamoto: J. Toxicol. Sci. 18, 83-93 (1993).

9) Y. Tomigahara, N. Suzuki, H. Tarui, K. Saito and H. Kaneko: J. Pestic. Sci. 39, 181-186 (2014)

10) P. C. Hirom, P. Millburn, R. L. Smith and R. T. Williams: Biochem. J. 129, 1071-1077 (1972).

11) R. T. Williams: "Species variations in drug biotransformation," Fundamentals of Drug Metabolism and Drug Disposition, ed. by B. N. LaDu, H. G. Mndel and E. L. Way, pp. 201-203, The Williams and Willkins Company, Baltimore, 1971.

12) M. M. Abou-El-Makarem, P. Millburn, R. L. Smith and R. T. Williams: Biochem. J. 105, 1289-1293 (1967)

13) K. Niinuma, Y. Kato, H. Suzuki, C. A. Tyson, V. Weizer, J. E. Dabbs, R. Froehlich, C. E. Green and Y. Sugiyama: Am. J. Physiol. 276, $1153-$ 1164 (1999).

14) H. Ishizuka, K. Konno, T. Shiina, H. Naganuma, K. Nishimura, K. Ito, H. Suzuki and Y. Sugiyama: J. Pharmacol. Exp. Ther. 290, 1324-1330 (1999).

15) M. Li, H. Yuan, N. Li, G. Song, Y. Zheng, M. Baratta, F. Hua, A. Thurston, J. Wang and Y. Lai: Eur. J. Pharm. Sci. 35, 114-126 (2008).

16) Y. Lai: Expert Opin. Drug Metab. Toxicol. 5, 1175-1187 (2009).

17) J. Miyamoto, H. Kaneko, D. H. Hutson, H. O. Esser, S. Gorbach and E. Dorn E (eds): "Pesticide Metabolism: Extrapolation from Animals to Man," Chapter 2, pp. 8-12, Blackwell Scientific Publications, Oxford, 1988. 